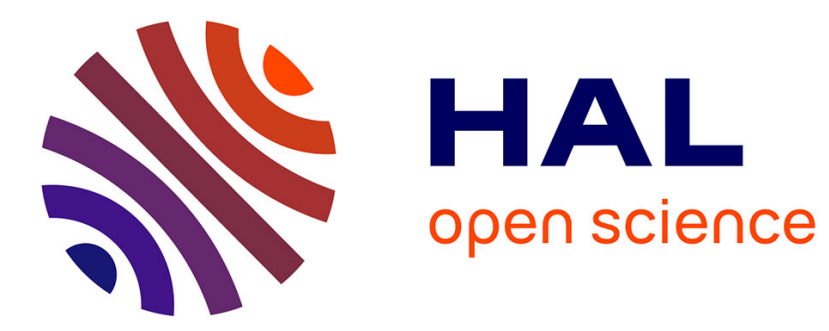

\title{
Location of the River Euphrates in the Late Miocene; dating of terrace gravel at Shireen, Syria
}

T. Demir, M. Pringle, S. Yurtmen, R. Westaway, D. Bridgland, A. Beck, K. Challis, G. Rowbotham

\section{- To cite this version:}

T. Demir, M. Pringle, S. Yurtmen, R. Westaway, D. Bridgland, et al.. Location of the River Euphrates in the Late Miocene; dating of terrace gravel at Shireen, Syria. eEarth, 2007, 2 (1), pp.27-34. hal00298233

\section{HAL Id: hal-00298233 \\ https://hal.science/hal-00298233}

Submitted on 17 Apr 2007

HAL is a multi-disciplinary open access archive for the deposit and dissemination of scientific research documents, whether they are published or not. The documents may come from teaching and research institutions in France or abroad, or from public or private research centers.
L'archive ouverte pluridisciplinaire HAL, est destinée au dépôt et à la diffusion de documents scientifiques de niveau recherche, publiés ou non, émanant des établissements d'enseignement et de recherche français ou étrangers, des laboratoires publics ou privés. 


\title{
Location of the River Euphrates in the Late Miocene; dating of terrace gravel at Shireen, Syria
}

\author{
T. Demir ${ }^{1}$, M. Pringle ${ }^{2}$, S. Yurtmen ${ }^{3}$, R. Westaway ${ }^{4,5}$, D. Bridgland ${ }^{6}$, A. Beck ${ }^{7}$, K. Challis ${ }^{8}$, and G. Rowbotham ${ }^{9}$ \\ ${ }^{1}$ Department of Geography, Harran University, 63300 Şanlıurfa, Turkey \\ ${ }^{2}$ Isotope Geosciences Laboratory, Department of Earth, Atmospheric, and Planetary Sciences, Massachusetts Institute of \\ Technology, Cambridge, MA 02139-4307, USA \\ ${ }^{3}$ Department of Geology, Çukurova University, 01330 Adana, Turkey \\ ${ }^{4}$ Faculty of Mathematics and Computing, The Open University, Eldon House, Gosforth, Newcastle-upon-Tyne NE3 3PW, UK \\ ${ }^{5}$ School of Civil Engineering and Geosciences, Newcastle University, Newcastle-upon-Tyne NE1 7RU, UK \\ ${ }^{6}$ Department of Geography, Durham University, Durham DH1 3LE, UK \\ ${ }^{7}$ School of Computing, University of Leeds, Leeds LS2 9JT, UK \\ ${ }^{8}$ Birmingham Archaeology, University of Birmingham, Birmingham B15 2TT, UK \\ ${ }^{9}$ School of Earth Sciences and Geography, Keele University, Staffordshire ST5 5BG, UK
}

Received: 31 August 2006 - Published in eEarth Discuss.: 12 December 2006

Revised: 22 February 2007 - Accepted: 10 March 2007 - Published: 17 April 2007

\begin{abstract}
We report gravel of the River Euphrates, capped by basalt that is Ar-Ar dated to $\sim 9 \mathrm{Ma}$, at Shireen in northern Syria. This gravel, preserved by the erosion-resistant basalt, allows us for the first time to reconstruct the history of this major river during the Late Miocene. In response to progressive regional surface uplift, the Euphrates extended SE by $\sim 800 \mathrm{~km}$ between the early Middle Miocene, when the coast was near Kahramanmaraş in southern Turkey, and the Pliocene, when it lay in western Iraq, east of the Arabian Platform uplands.
\end{abstract}

\section{Introduction}

Due to their action of transporting the products of erosion, and thus facilitating the isostatic rebound that has contributed to the systematic growth of topography in the Late Cenozoic, large rivers have had a significant role in long-timescale global change. However, relatively few pre-Pleistocene upland localities are known with demonstrable evidence that an extant major river was present. Examples include: Australian rivers with records back to the Palaeogene (Stevenson and Brown, 1989; Nott, 1992); rivers in eastern Europe that are documented back to the Late Miocene (e.g., Matoshko et al., 2004); and the Colorado in the SW USA, which has been reconstructed back to the Middle Miocene (e.g., McKee and McKee 1972; Lucchitta, 1979). However, in most other regions one can only infer roughly where rivers once

Correspondence to: R. Westaway

(robwestaway@tiscali.co.uk) flowed from the provenance of sediment reaching lowland or offshore depocentres, with no direct supporting evidence.

With a length of $\sim 2800 \mathrm{~km}$, the Euphrates is the longest river in SW Asia. From its source in NE Turkey it flows initially west and south, then SE across the Arabian Platform in Syria and Iraq (Fig. 1) to the Persian Gulf. The Arabian Platform was a marine depocentre until the Middle-Late Miocene (e.g., Lovelock, 1984). Fluvial sand and gravel are widespread near its northern margin around Kahramanmaraş (e.g., Derman, 1999; Fig. 1), dated to the early Middle Miocene (Langhian; $\sim 16 \mathrm{Ma}$ ) using interbedded basalt (Arger et al., 2000) and shallow marine sediments (Karig and Kozlu, 1990). The diverse clast content, including metamorphic lithologies not found in situ in the Arabian Platform, indicates that a major river, draining at least part of the modern upper Euphrates catchment, reached the sea here at this time (1, Fig. 1).

A staircase of Late Cenozoic fluvial terraces records the evolution of the Euphrates along its present course, indicating net incision by $\sim 110 \mathrm{~m}$ at Birecik (Sanlaville, 2004; Demir et al., 2004), near the Turkey-Syria border, and by $\sim 70 \mathrm{~m}$ at Khan al-Baghdadi (Tyráček, 1987) at the eastern margin of the Arabian Platform uplands (Fig. 1). Across eastern Syria (around and below Raqqa, where much less incision has occurred since both the Late Pliocene and the late Early Pleistocene; Westaway et al., 2005a) and western Iraq, the modern Euphrates valley is flanked by extensive older stacked fluvial gravels (attributed to the ancestral $\mathrm{Eu}-$ phrates from their diverse clast content), which indicate the course of the river in the Early Pliocene (e.g., Besançon and Geyer, 2003; 3, Fig. 1). However, its modern course farther

Published by Copernicus GmbH on behalf of the European Geosciences Union. 


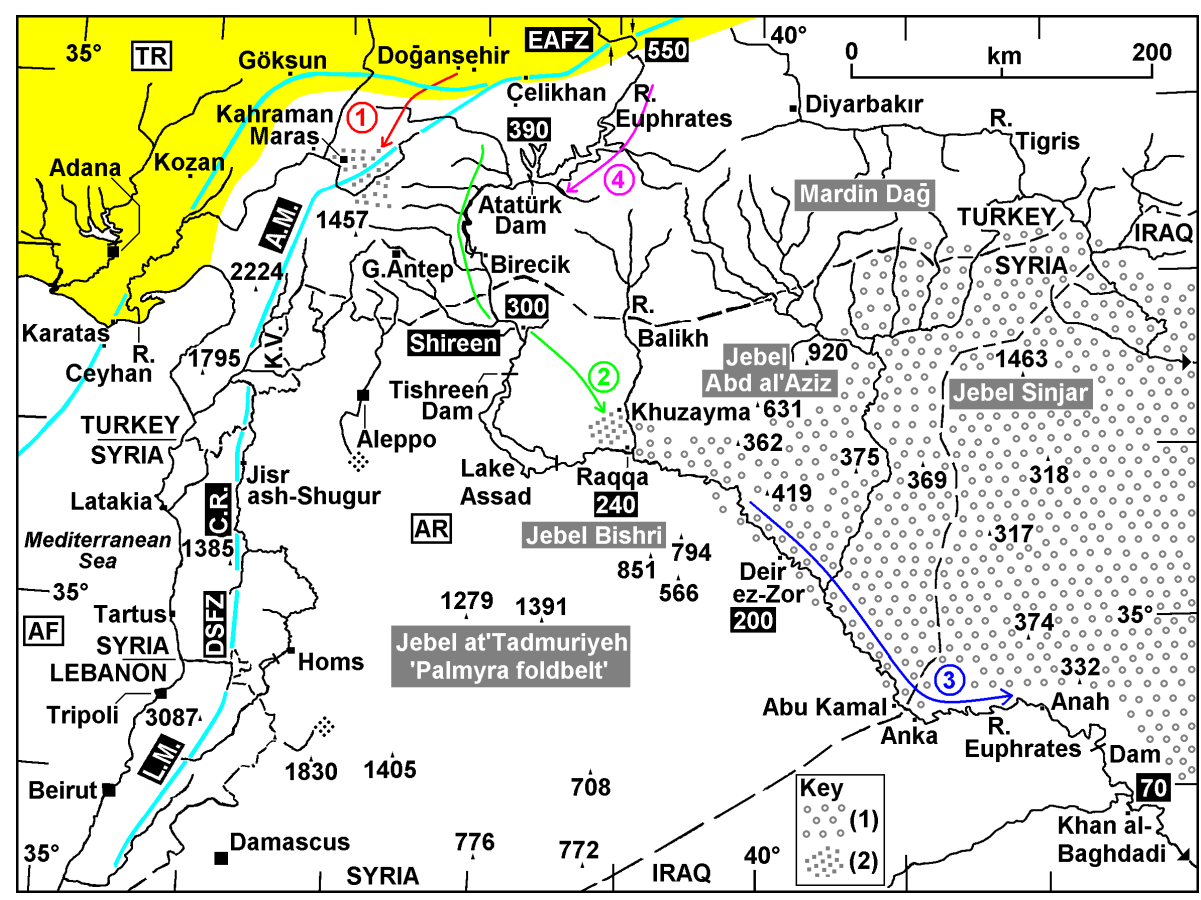

Fig. 1. Map locating the study area in relation to the River Euphrates (with its altitude a.s.l. marked at key sites) and the active left-lateral faults (after Westaway, 2004, coloured light blue) bounding the Arabian (AR), African (AF) and Turkish (TR) plates. Mountain ranges forming by distributed shortening along the DSFZ are: L.M., Lebanon Mountains; C.R., Syrian Coastal Range (Jebel Nusayriyah); and A.M., Amanos Mountains. K.V. denotes the Karasu Valley. The Anatolian crustal province is shaded yellow, except where offshore. The suture of the Neotethys Ocean follows its southern margin, also marking the northern limit of the Arabian Platform. Ophiolitic rock (chert, basalt, etc.) from this suture zone and metamorphic rock (quartzite, calcschist, etc.) from Anatolia, farther north, are major constituents of the Euphrates gravels. Cenozoic folding, superimposed on regional uplift, has created the uplands within the Arabian Platform labelled in grey. In the Key, (1) denotes outcrop of the Upper Fars Formation; (2) denotes concentrations of stacked fluvial sand and gravel, from the early Middle Miocene and (?) Late Miocene. In the figure, 1, 2, 3 and 4 indicate the Euphrates in the Middle Miocene, Late Miocene, Pliocene, and Pleistocene, respectively coloured red, green, dark blue and purple. 1, 3 and 4 are from previous work; 2 is inferred in this study.

upstream (4, Fig. 1) is no older than $\sim 2 \mathrm{Ma}$, from the ratio of the offset of its gorge through the East Anatolian fault zone (EAFZ) to the total slip on this fault zone (e.g., Westaway, 2004).

There is thus a significant information gap, spanning the Late Miocene and more, for which the geometry of the Euphrates has been obscure. One view (Arger et al., 2000) has been that it terminated in a large palaeo-lake north of the modern Atatürk Dam (Fig. 1). Another possibility, suggested by the modern drainage geometry (Fig. 1), is that it flowed SW into the Mediterranean Sea, along either the Karasu Valley or the line of the modern River Ceyhan (Fig. 1), before being diverted eastward, possibly due to the initiation at $\sim 4 \mathrm{Ma}$ of the modern geometry of the northern Dead Sea Fault Zone (DSFZ), which is strongly transpressive, with left-lateral slip accompanying localised surface uplift (e.g., Westaway, 2004; Seyrek et al., 2007). The most recent estimate of the initiation of this modern geometry of strike-slip faulting is $3.73 \pm 0.05 \mathrm{Ma}$ (Westaway et al., 2006a), based on evidence from the SW part of the EAFZ to the east of
Kahramanmaraş (Fig. 1). Previous work on reconstructing Plio-Pleistocene fluvial systems in Syria (Bridgland et al., 2003) and Turkey (Westaway et al., 2004, 2005b, 2006b) has required the documentation of fragmentary sedimentary sections, often with dimensions of only a few square metres. We have identified one such site, at Shireen in northern Syria (Fig. 1), where fluvial gravel - attributed to the Euphrates and preserved due to capping by basalt - has been dated to $\sim 9$ Ma by Ar-Ar dating of the basalt, thus demonstrating the location of this major river in the Late Miocene.

\section{Regional geology and tectonics}

Most outcrop in this part of northern Syria (Fig. 2) consists of Cenozoic marine carbonates. Late Eocene chalky and clayey limestone is overlain by $\sim 70 \mathrm{~m}$ of Oligocene hard crystalline limestone and dolomitic limestone (Ponikarov et al., 1967). During deposition of these sediments the northern Arabian Platform formed a seaway linking the Mediterranean Sea and Indian Ocean. 
Table 1. Euphrates terraces in the Shireen area.

\begin{tabular}{llllll}
\hline Terrace & $\begin{array}{l}\text { Height } \\
(\mathrm{m})\end{array}$ & Description & MIS & $\begin{array}{l}\text { Age } \\
(\mathrm{ka})\end{array}$ & $\begin{array}{l}\text { Rate } \\
(\mathrm{mm} / \mathrm{a})\end{array}$ \\
\hline Qf0 & +8 & Fluvial sand/gravel & 2 & 15 & 0.067 \\
QfI & +15 & Fluvial sand/gravel & 6 & 140 & 0.057 \\
QfII & +39 & Fluvial sand/gravel & 12 & 430 & 0.074 \\
QfIII & +70 & Fluvial sand/gravel & 22 & 870 & 0.072 \\
Shireen & +70 & Fluvial sand/gravel & & 8900 & 0.007 \\
\hline
\end{tabular}

After Oguchi (2001) and Sanlaville (2004), with our tentative age estimates. These inferred ages for the deposits forming terraces Qf0 and QfI are consistent with the results of Kuzucuoğlu et al. (2004) farther upstream in the Euphrates, at Birecik (Fig. 1). See Demir et al. (2007) for details of the locations and heights of terrace deposits selected as representative of terraces QfII and QfIII in this area. Notation in brackets is after Oguchi (2001). Incision rates are calculated relative to $7 \mathrm{~m}$ above modern low-stage (autumn) pre-dam river level. MIS denotes the marine oxygen isotope timescale.

Unconformable Miocene marine limestone was assigned by Ponikarov et al. (1967) to the Jeribe Formation. This stratigraphic unit has regional significance, extending from Syria to Iran, dated to the early Middle Miocene (Langhian; James and Wynd, 1965; Alsharhan and Nairn, 1995). Diverse carbonate facies are evident, suggesting rapidlychanging shallow-marine conditions. This limestone is overlain by deposits assigned by Ponikarov et al. (1967) to the Lower Fars Formation, another regionally significant unit, of late Middle Miocene (Burdigalian) age (James and Wynd, 1965; Alsharhan and Nairn, 1995). Around Shireen this consists of interbedded green calcareous clay and marl, red mudstone and white limestone with occasional gypsum layers, and is no more than a few tens of metres thick. Farther north near the Turkish border, conglomerate and crossbedded sandstone are also assigned to this unit. These sediments indicate marginal marine conditions with input of clastic sediment from the north. By this time a land bridge connected Arabia with Turkey (between Aleppo and Kahramanmaraş; Fig. 1), isolating the Mediterranean Sea from the Mesopotamian Basin of Syria, Iraq and Iran.

No younger stacked sediments are found in this area. However, east of Raqqa (Fig. 1) there is extensive outcrop of the Upper Fars Formation, consisting of up to $\sim 250 \mathrm{~m}$ of clay, siltstone, fine-grained sandstone and gypsum. These deposits record a marine to lagoonal or lacustrine transition, which occurred in the Late Miocene (James and Wynd, 1965; Alsharhan and Nairn, 1995). Younger stacked terrestrial sediments, assigned to the Pliocene and correlated with the Bakhtiari Formation of Iraq, also crop out widely in eastern Syria, notably around Deir ez-Zor. These consist of sand and gravel, with a general upward-coarsening trend, with calcareous clay and gypsum interbeds (Ponikarov et al., 1967), indicating a lacustrine depocentre with fluvial input. The clasts include igneous and metamorphic rocks derived from eastern Turkey, indicating that the Euphrates reached the area at that time (3, Fig. 1).

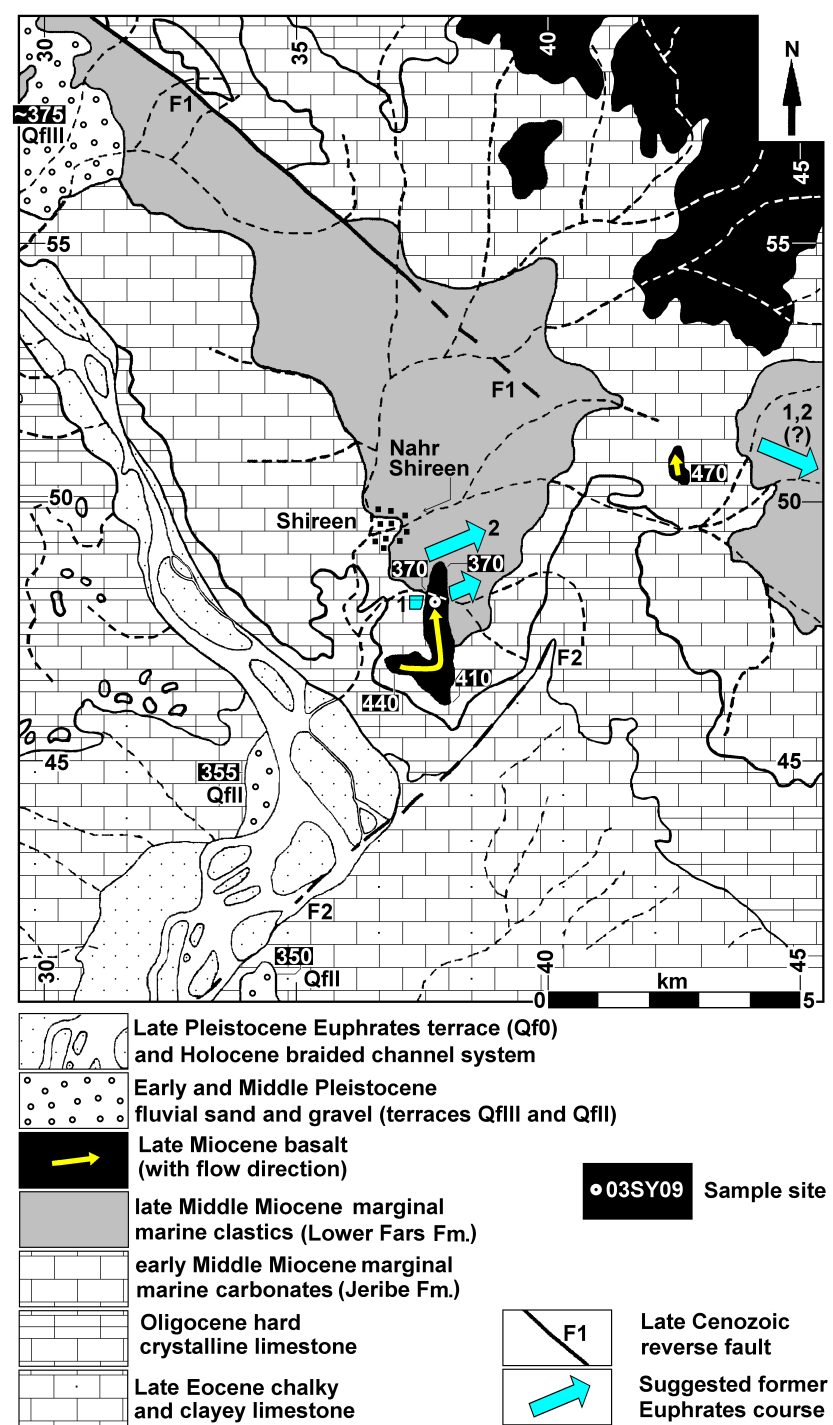

Fig. 2. Geological map of the Shireen area, after Ponikarov (1966), as modified by Oguchi (2001), showing the location of basalt sample 03SY09. The underlying fluvial gravel was not recognised in this mapping, presumably because the modern quarry had not yet opened. 1 indicates the inferred course of the Euphrates before this basalt eruption; 2 indicates how we suggest it adjusted immediately afterward. The Euphrates was locally $\sim 300 \mathrm{~m}$ a.s.1. in the southern part of this map area, rising to $\sim 305 \mathrm{~m}$ a.s.l. in the north; construction of the Tishreen Dam in the 1990s has impounded it at $\sim 325 \mathrm{~m}$ (see Fig. S2 in the online supplement (http://www.electronic-earth.net/2/27/2007/ ee-2-27-2007-supplement.zip) for more detail). Pleistocene gravels are labelled consistent with Table 1; based on its mapped extent in relation to the topography, the deposit assigned to terrace QfIII is $\sim 45 \mathrm{~m}$ thick, its base and top beting $\sim 430$ and $\sim 475 \mathrm{~m}$ a.s.1. (see Demir et al., 2007, for more details). Shireen is an abbreviated phonetic spelling of the name of the village in our study area. Alternative spellings, in full, transliterated from Arabic on maps and other publications, include Shirrin esh-Shemaliyeh, Shirrin ashShamaliyah, Serrin Esh-Shamaligeh, Surrien Shamali, and Sarine Shamali. 


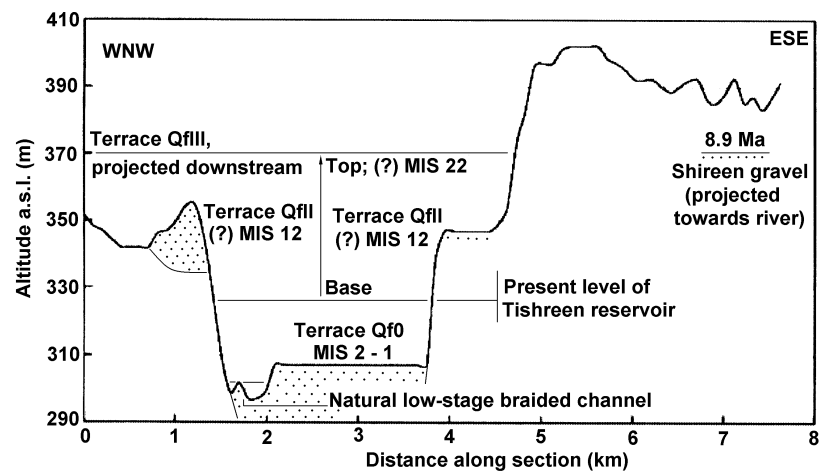

Fig. 3. Cross-section through the Euphrates terrace staircase, passing $\sim 5 \mathrm{~km} \mathrm{SSW}$ of Shireen (crossing the river valley near the SW corner of Fig. 2), modified after Oguchi (2001) (cf. Table 1). The deposits forming Euphrates terrace QfIII are projected into this section line from their location near the NW corner of Fig. 2, assuming a downstream decrease in river level of $5 \mathrm{~m}$, consistent with a typical downstream gradient of the Euphrates channel of $\sim 0.3 \mathrm{~m} \mathrm{~km}^{-1}$.

Following the Eocene closure of the Neotethys Ocean (see Fig. 1 caption), northward motion of the African Plate (AF) was accommodated for tens of millions of years by distributed crustal shortening. The principal shortening mechanism within the Arabian Platform involved folding of anticlines above blind reverse faults (e.g., Rigo de Righi and Cortesini, 1964; Chaimov et al., 1990; Coşkun and Coşkun, 2000). The DSFZ developed in the early Middle Miocene ( 19 Ma; Garfunkel, 1981), separating the Arabian Plate (AR) from the African Plate. Initially, it seems, its leftlateral slip was taken up by continued distributed shortening within the northern Arabian Platform (Westaway, 2004). At $\sim 4 \mathrm{Ma}$ (Westaway, 2004; Westaway et al., 2006a; Seyrek et al., 2007) the modern throughgoing linkage (Fig. 1) between the DSFZ and EAFZ developed, since when many of these anticlines have been inactive. However, the northern DSFZ is strongly transpressive (e.g., Westaway, 2004; Gomez et al., 2006; Seyrek et al., 2007). The component of distributed shortening along it has caused localised growth of topography (e.g., Westaway, 2004), notably in the Lebanon Mountains, Syrian Coastal Range and Amanos Mountains (Fig. 1). Superimposed on all these local effects has been progressive southward regional tilting of the land surface, due to the typical northward increase in rates of post-Middle Miocene regional uplift (e.g., Arger et al., 2000). All these factors, plus the need to maintain a downstream channel gradient, must be considered when reconstructing the evolution of the Euphrates.

\section{The Shireen site}

The site is in the left flank of the Euphrates valley $(\sim 35 \mathrm{~km}$ $\mathrm{S}$ of the Turkish border, $\sim 60 \mathrm{~km}$ downstream of Birecik),
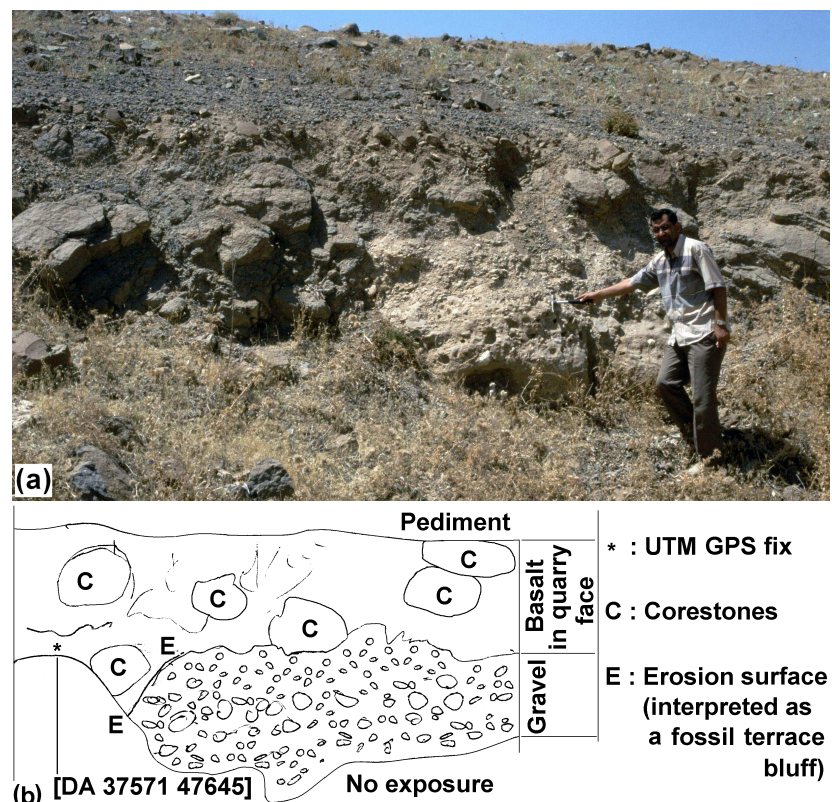

(b)

Fig. 4. (a) Field photograph, looking west at the Shireen quarry exposure of gravel and overlying basalt. T. Demir provides scale. (b) Field sketch of this exposure.

$\sim 4 \mathrm{~km} \mathrm{E}$ of the modern river, whose course locally bends from SE to SW (Figs. 1, 2). This region is transected by both SE- and SW-trending reverse faults, which took up crustal shortening prior to the initiation of the EAFZ, causing localised offsets and warpings in the stacked Cenozoic sediments. The present local relief results from this deformation, differential erosion (the Eocene clayey limestone being easily erodable) and fluvial incision. Young incision is revealed by Euphrates terraces (Table 1), the most prominent around Shireen being QfII and Qf0 (Fig. 2), the latter assigned to MIS 2 (Fig. 3)

About $2 \mathrm{~km} \mathrm{SE}$ of Shireen, the road along the Euphrates valley passes through basalt, which unconformably overlies the stacked Middle Miocene succession (Fig. 2). At UTM coordinates [DA 37748 47784], a track heads west to a quarry, where the basalt overlies gravel (Fig. 4). The up to $\sim 1 \mathrm{~m}$ thickness of gravel visible (base not exposed) is cemented and highly weathered. Clasts, set in a sandy matrix, and typically rounded to subrounded, are poorly-sorted but show stratification and some evidence of fining-upward (maximum size, $\sim 10 \mathrm{~cm}$ ). Intact clasts of both chert and limestone are abundant, the largest being of limestone, but clasts of other lithologies have weathered to powder or disintegrated completely, leaving voids within the matrix. The cemented nature of the deposit and the fact that many clasts are unidentifiable have precluded any stone count analysis. The basalt-gravel contact is subhorizontal, except at the left-hand (south) end of the exposure, where the basalt covers a downward bluff at the edge of the gravel (Fig. $4 \mathrm{~b}$ ). The $\sim 3 \mathrm{~m}$ of basalt is 
likewise highly weathered. Above the quarry face the in situ basalt is obscured by a pediment of basalt blocks, whereas within this face it consists of corestones surrounded by rotten rock. Sample 03SY09 was collected from a corestone for Ar-Ar dating.

This basalt erupted from a neck at $\sim 440 \mathrm{~m}$ a.s. $1 ., 1.6 \mathrm{~km}$ SSW of this site (Fig. 2). It flowed initially east for $1 \mathrm{~km}$ before apparently becoming deflected northward along a local tributary valley, descending from $\sim 400$ to $\sim 370 \mathrm{~m}$ a.s. 1 . in $1 \mathrm{~km}$ distance. However, the most distal $\sim 1 \mathrm{~km}$ of this flow, including this site, is at a roughly constant level of $\sim 370$ m a.s.1.

\section{Age of the Shireen volcanism and its regional context}

Ar-Ar dating gave an age of $8809 \pm 73 \mathrm{ka}( \pm 2 \sigma)$ for our sample (Fig. 5). It is thus Late Miocene, therefore much older than the "Early Pleistocene" age, shown on the local geological map sheet. Thius younger age seems to have been inferred (Ponikarov et al., 1967) by analogy with the Pleistocene basalts in the nearby Karasu Valley (cf. Yurtmen et al., 2002; Seyrek et al., 2007). However, the degree of weathering is more characteristic of the Late Miocene Homs basalt of western Syria ( $\sim 6$ Ma; Mouty et al., 1992) and Karaçay basalt of SW Turkey ( $\sim 7 \mathrm{Ma}$; Westaway et al., 2005b).

Our new date also fits the existing dating framework for the Yavuzeli Basalt in adjacent parts of Turkey. For instance, Ulu (1996a) mentioned a K-Ar date of 10.6 $\pm 0.2 \mathrm{Ma}$ for one of the Yavuzeli Basalt flow units east of Birecik (Fig. 1); Terlemez et al. (1997) cited an unpublished oil-industry report in support of dating this phase of volcanism to $\sim 9-8 \mathrm{Ma}$. Our new date lies within the range of these earlier estimates. Farther northeast, the voluminous Siverek Volcanics, which crop out widely between Diyarbakır and the River Euphrates (Fig. 1) have an age of $7.8 \pm 1.7 \mathrm{Ma}( \pm 2 \sigma)$, determined as the weighted mean of three K-Ar dates (Bridgland et al., 2007), making them also broadly synchronous with the Shireen volcanism.

\section{Late Miocene location of the Euphrates}

Although exposure and preservation are not ideal, we interpret the gravel in Figs. 2b, c as fluvial. Since chert is relatively rare in the Cenozoic carbonate sequence of the Arabian Platform, we consider it probable that the abundant chert clasts originated from the ophiolite suite at the Neotethys suture, $\sim 200 \mathrm{~km}$ farther north (Fig. 1). The unidentifiable weathered clasts may thus be of igneous constituents from this ophiolite. The gravel thus indicates the presence of the ancestral River Euphrates in this area at $\sim 9 \mathrm{Ma}$.

The disposition of the basalt and gravel indicates that the former cascaded into the Euphrates valley from the south, the evidence (Fig. 4b) suggesting that it reached beyond the terrace bluff of what was at this time a low terrace on the north side of the river. The basalt thus covered the contemporaneous river thalweg. This evidence is indeed similar to what is observed elsewhere, where basalt flows have interacted with river valleys (e.g., Westaway et al., 2004, 2006b; Maddy et al., 2005). By analogy, the Euphrates will have subsequently incised around the northern tip of the Shireen basalt flow.

We have been unable to identify clear palaeo-flow indicators (e.g., cross-beddng, clast imbrication) in the Shireen gravel. However, from the regional context we consider it likely that the Euphrates flowed eastward through this site at this time, adjusting from course 1 to course 2 in Fig. 2 as a result of the basalt-damming of its valley. This eastward course most likely led towards Raqqa, shown schematically as course 2 in Fig. 1. NW of Raqqa, a succession of fluvial sands and gravels, locally $>10 \mathrm{~m}$ thick (base not exposed), attributed to the Euphrates from their polymict lithology (Table 2), crops out over an area of $\sim 200 \mathrm{~km}^{2}$ (Fig. 1) at up to $\sim 320 \mathrm{~m}$ a.s.l., $\sim 80 \mathrm{~m}$ above the modern river. These gravels adjoin the western end of the outcrop of Upper Fars Formation (Fig. 1), but like the basalt were inferred in the 1960s mapping to be "Early Pleistocene" (Ponikarov, 1966). These deposits appear much less weathered than those at Shireen, but the Raqqa area has much less annual rainfall $(<200 \mathrm{~mm}$, against $\sim 350 \mathrm{~mm}$ ) and the Pleistocene Euphrates terraces have locally experienced minimal weathering, in contrast with farther NW. We thus suggest that these Raqqa gravels mark the downstream limit of the SE course of the Euphrates through Shireen, recorded by the gravel there, and also delineate the paleocoastline adjoining the contemporaneous Late Miocene depocentre of the Upper Fars Formation. Subsequently, due to continuing regional uplift, the sea retreated from this area and the Euphrates thus extended downstream across eastern Syria and Iraq (3, Fig. 1).

Previous studies (e.g., Brew et al., 1997; Besançon and Geyer, 2003) have noted that the SE-trending course of the Euphrates below Raqqa is structurally controlled, by local downwarping along the Euphrates Fault Zone. We thus suggest that in the Late Miocene, the reach of the ancestral Euphrates between Shireen and Raqqa was also controlled by the same lineation (Fault F1 in Fig. 2). We infer that, at a later stage, processes in the Shireen area (including local faulting and folding, the latter including NW downthrow on fault F2; differential erosion; southward tilting) disrupted this course and deflected the river to form its modern looped course upstream of Raqqa, which is now flooded by the Lake Assad reservoir (Fig. 1).

\section{Post-Miocene uplift and fluvial incision}

Regarding the incision history, we note that in SE Turkey the $+60 \mathrm{~m}$ Euphrates terrace (QfIII) has been thought to date from MIS 12 and, it seems, the volumetrically most significant gravel (of terrace QfV, reaching $+110 \mathrm{~m}$ ) has been thought to have finished aggrading in MIS 22 (Sanlaville, 


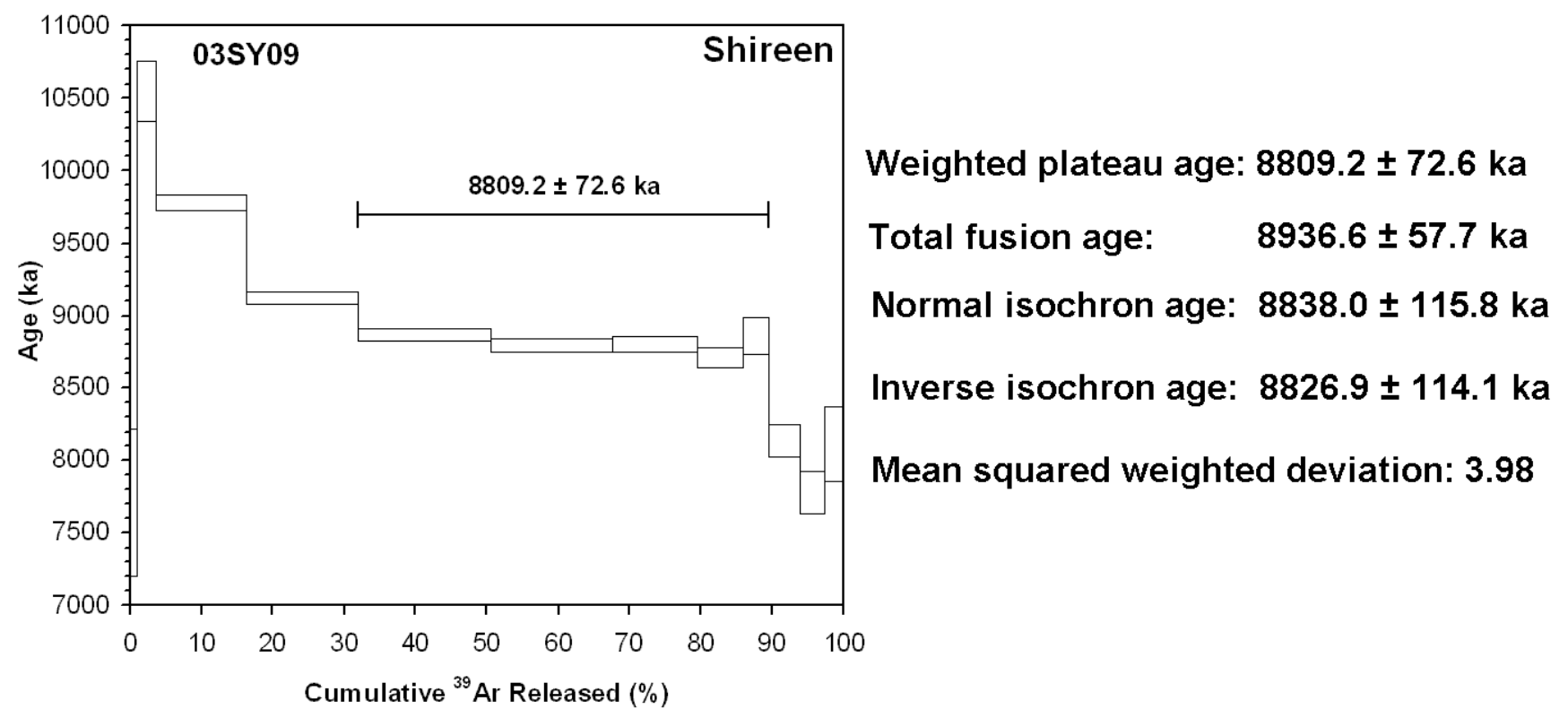

Fig. 5. Main part of figure shows an age spectrum derived from step-heating of sample 03SY09. The horizontal bar indicates the heating steps used to calculate the age estimate from step-heating. To the right are listed four age determinations for the same sample based on different analysis methods; the internal consistency of these different numerical ages and their low error margins demonstrate the reliability of this date (see Demir et al., 2007, for more details). Following previous recommendations (e.g., Harford et al., 2002), the calculation based on step-heating is considered definitive. Calibration of the neutron flux during sample irradiation utililised the U.S. Geological Survey Taylor Creek Rhyolite sanidine standard TCR-2A with an assigned age of 28.34 Ma (after Renne et al., 1998). The material dated was groundmass, after magnetic separation, prepared following the procedure used previously by Yurtmen et al. (2002) and Westaway et al. (2004, 2005b, 2006b). Analysis was carried out at the Isotope Geosciences Laboratory, Massachusetts Institute of Technology, the method used being essentially the same as that described by Harford et al. (2002). Age calculations have assumed the decay constants of Steiger and Jäger (1977).

Table 2. Gravel composition near Khuzayma.

\begin{tabular}{lcc}
\hline Lithology & Number & $\%$ \\
\hline Quartzite & 89 & $36 \%$ \\
Chert or flint & 55 & $22 \%$ \\
Quartz & 33 & $13 \%$ \\
Mafic igneous & 32 & $13 \%$ \\
Limestone or marble & 18 & $7 \%$ \\
Calcschist & 10 & $4 \%$ \\
Hard mudstone & 8 & $3 \%$ \\
Sandstone & 2 & $1 \%$
\end{tabular}

Summary of results of a stone count of 247 clasts in the 16-32 mm size fraction, collected from the Euphrates gravel at [DV 98374 96614], to the south of Khuzayma (Fig. 1).

2004; Demir et al., 2004). Taking account of the regional southward tapering in uplift rates (Arger et al., 2000), we suggest that the upper part of the principal Euphrates gravel around Shireen (reaching $+70 \mathrm{~m}$, assigned to terrace QfIII; Figs. 2, 3) likewise probably aggraded no later than MIS 22. Other possible correlations of the terrace gravels between the Shireen and Birecik areas and with MIS stages are discussed by Demir et al. (2007). The minimal net incision at Shireen, estimated between $\sim 8.8 \mathrm{Ma}$ and $\sim 0.9 \mathrm{Ma}$, is attributed in part to the local downwarping caused by slip on fault F2 (Fig. 2) and in part to the dramatic downstream lengthening of the Euphrates channel that accompanied the coastal retreat (Fig. 1). The $\sim 45 \mathrm{~m}$ thickness of the QfIII terrace gravel (Fig. 3) indicates that the Euphrates did not remain at a constant level (relative to the bedrock geology in the Shireen area) during this span of time; it evidently incised to within $\sim 25 \mathrm{~m}$ of its present level before aggrading back to $\sim 70 \mathrm{~m}$ above its present level, before re-incising (during the Middle and Late Pleistocene, given our preferred set of terrace ages) to its present level.

Fault F2 in Fig. 2 is presumed (like many others in the northern Arabian Platform; e.g., Chaimov et al., 1990; Brew et al., 1997; Litak et al., 1997; Coşkun and Coşkun, 2000) to have been active at some stage between the Late Miocene and Middle Pliocene; it can be seen in Fig. 2 to have offset and warped the local Miocene and older stratigraphy. On the upthrown side of the fault the Euphrates has incised into Eocene limestone, whereas on the downthrown side it has only reached the stratigraphically overlying Oligocene limestone. Using the geological map and the additional topographic information in the online supplement (http://www.electronic-earth.net/2/27/2007/ 
ee-2-27-2007-supplement.zip), the overall amount of downthrow and structural warping across this fault can be estimated at $\sim 100 \mathrm{~m}$. Assuming all this deformation has occurred since $\sim 9 \mathrm{Ma}$ (because the flow of the Shireen basalt was not directed in the down-dip direction that now pertains as a result of this warping), the Shireen basalt and associated gravel would be $\sim 100 \mathrm{~m}$ higher than they now are, or $\sim 170 \mathrm{~m}$ above the Euphrates.

Regarding the effect of coastal retreat, we estimate that Shireen was not far (perhaps $\sim 100 \mathrm{~km}$ ) upstream of the coastline at $\sim 9 \mathrm{Ma}$ (see above). The Euphrates palaeogradient between this point and the coastline was probably very low, and so its change in height between these points can be neglected in this approximate calculation. If any subsequent global sea-level fall is also neglected, some $\sim 470 \mathrm{~m}$ of uplift can thus be estimated at Shireen since $\sim 9 \mathrm{Ma}$, from the $\sim 370 \mathrm{~m}$ a.s.l. present-day altitude of the the Shireen gravel plus the $\sim+100 \mathrm{~m}$ correction for subsequent local structural warping. For comparison, west of Shireen, Early Miocene marine limestone and Middle Miocene marine clastics are both found at up to $\sim 500 \mathrm{~m}$ a.s.l. (Fig. 2), and would probably be somewhat higher if the localised warping in the Shireen area had not occurred. Their disposition is consistent with the calculation using the Shireen gravel; thus, $\sim 470 \mathrm{~m}$ seems a reasonable estimate for the regional uplift in the Shireen area since $\sim 9 \mathrm{Ma}$, greatly in excess of the observed fluvial incision, due to the effect of downstream channel-lengthening.

\section{Conclusions}

The discovery of Euphrates gravel, capped and preserved by basalt, dated to $\sim 9 \mathrm{Ma}$, constrains the evolution of the River Euphrates in northern Syria during the Late Miocene. In the early Middle Miocene, the ancestral Euphrates reached the sea near Kahramanmaraş in southern Turkey (1, Fig. 1). Regional uplift in the Late Miocene caused the coast to retreat south and east, and the river thus lengthened downstream to the vicinity of Raqqa in northern Syria (2, Fig. 1). Continuing regional uplift in the Pliocene caused the coast to retreat farther southeast, and the river extended to the eastern margin of the modern Arabian Platform uplands (3, Fig. 1).

Acknowledgements. Supported by the Council for British Research in the Levant (D. Bridgland) and by Harran University Scientific Research Council (T. Demir). W. Olszewski helped with documentation of the Ar-Ar dating results. We thank J. Vandenberge and an anonymous reviewer for their thoughtful and constructive comments. This study contributes to IGCP 518 "Fluvial sequences as evidence for landscape and climatic evolution in the Late Cenozoic". Full documentation of the Ar-Ar dating and land surface imagery of the study region is provided in the online supplement.

Edited by: J. Smit

\section{References}

Alsharhan, A. and Nairn, A.: Tertiary of the Arabian Gulf: sedimentology and hydrocarbon potential, Palaeogeography, Palaeoclimatology, Palaeoecology, 114, 369-384, 1995.

Arger, J., Mitchell, J., and Westaway, R.: Neogene and Quaternary volcanism of south-eastern Turkey, in: Tectonics and Magmatism of Turkey and the Surrounding Area, edited by: Bozkurt, E., Winchester, J. A., and Piper, J. D. A., Geological Society, London, Special Publication, 173, 459-487, 2000.

Besançon, J. and Geyer, B.: La géomorphologie de la basse vallée de l'Euphrate Syrien, in: La Basse Vallée de l'Euphrate Syrien du Néolithique a l'avenement de l'Islam., edited by: Geyer, B. and Montchambert, J.-Y., vol. 1. Institut Français du Proche Orient, Beirut, Lebanon, 7-59, 2003.

Brew, G., Litak, R., Seber, D., Barazangi, M., Sawak, T., and AlIman, A.: Basement depth and sedimentary velocity structure in the northern Arabian Platform, eastern Syria, Geophys. J. Int., 128, 617-631, 1997.

Bridgland, D., Demir, T., Seyrek, A., Pringle, M., Westaway, R., Beck, A., Yurtmen, S., and Rowbotham, G.: Dating Quaternary volcanism and incision by the River Tigris at Diyarbakır, SE Turkey, J. Quat. Sci., 22, 387-393, 2007.

Bridgland, D., Philip, G., Westaway, R., and White, M.: A long Quaternary terrace sequence in the valley of the River Orontes, near Homs, Syria, Current Science, 84, 1080-1089, 2003.

Chaimov, T., Barazangi, M., Al-Saad, D., Sawaf, T., and Gebran, A.: Crustal shortening in the Palmyride fold belt, Syria, and implications for movement along the Dead Sea fault system, Tectonics, 9, 1369-1386, 1990.

Coşkun, B. and Coşkun, S.: The Dead Sea Fault and related subsurface structures, Gaziantep Basin, SE Turkey, Geological Magazine, 137, 175-192, 2000.

Demir, T., Pringle, M., Yurtmen, S., Westaway, R., Bridgland, D., Beck, A., Challis, K., and Rowbotham, G.: Reply to interactive comment by J. Vandenberghe on "Location of the River Euphrates in the Late Miocene; dating of terrace gravel at Shireen, Syria”, by Demir, T., Pringle, M., Yurtmen, S., Westaway, R., Bridgland, D., Beck, A., Challis, K., and Rowbotham, G., eEarth Discuss., 1, 13 pp (published online), 2007.

Demir, T., Yeşilnacar, İ., and Westaway, R.: River terrace sequences in Turkey: sources of evidence for lateral variations in regional uplift, Proceedings of the Geologists' Association, 115, 289311, 2004.

Derman, A.: Braided river deposits related to progressive Miocene surface uplift in Kahraman Maraş area, SE Turkey, Geological Journal, 34, 159-174, 1999.

Garfunkel, Z.: Internal structure of the Dead Sea leaky transform (rift) in relation to plate kinematics, Tectonophysics, 80, 81-108, 1981.

Gomez, F., Khawlie, M., Tabet, C., Darkal, A. N., Khair, K., and Barazangi, M.: Late Cenozoic uplift along the northern Dead Sea transform in Syria and Lebanon, Earth Planet. Sci. Lett., 241, 913-931, 2006.

Harford, C. L., Pringle, M. S., Sparks, R. S. J., and Young, S. R.: The volcanic evolution of Montserrat using ${ }^{40} \mathrm{Ar} /{ }^{39} \mathrm{Ar}$ geochronology, in: The eruption of the Soufrière Hills volcano, Montserrat, from 1995 to 1999, edited by: Druitt, T. H. and Kojkelaar, B. P., Geological Society, London, Memoirs, 21, 93-113, 2002. 
James, G. and Wynd, J.: Stratigraphic nomenclature of Iranian Oil Consortium Agreement Area, American Association of Petroleum Geologists' Bulletin, 49, 2182-2245, 1965.

Karig, D. and Kozlu, H.: Late Palaeogene-Neogene evolution of the triple junction near Maraş, south-central Turkey, J. Geological Soc., London, 147, 1023-1034, 1990.

Kuzucuoğlu, C., Fontugne, M., and Mouralis, D.: Holocene terraces in the Middle Euphrates valley between Halfeti and Karkemish (Gaziantep, Turkey), Quaternaire, 15, 195-206, 2004.

Litak, R. K., Barazangi, M., Beauchamp, W., Seber, D., Brew, G., Sawaf, T., and Al-Youssef, W.: Mesozoic-Cenozoic evolution of the intraplate Euphrates fault system, Syria; implications for regional tectonics, J. Geological Soc., London, 154, 653-666, 1997.

Lovelock, P.: A review of the tectonics of the Middle East region, Geological Magazine, 121, 577-587, 1984.

Lucchitta, I.: Late Cenozoic uplift of the SW Colorado Plateau and adjacent lower Colorado River region, Tectonophysics, 61, 6395, 1979.

Maddy, D., Demir, T., Bridgland, D., Veldkamp, A., Stemerdink, C., van der Schriek, T., and Westaway, R.: An obliquitycontrolled Early Pleistocene river terrace record from western Turkey?, Quat. Res., 63, 339-346, 2005.

Matoshko, A., Gozhik, P., and Danukalova, G.: Key Late Cenozoic fluvial archives of eastern Europe: the Dniester, Dnieper, Don and Volga, Proceedings of the Geologists' Association, 115, 141-173, 2004.

McKee, E. D. and McKee, E. H.: Pliocene uplift of the Grand Canyon region - time of drainage adjustment, Geological Soc. Am. Bull., 83, 1923-1932, 1972.

Mouty, M., Delaloye, M., Fontignie, D., Piskin, O., and Wagner, J.J.: The volcanic activity in Syria and Lebanon between Jurassic and Actual, Schweizerische Mineralogische und Petrographische Mitteilungen, 72, 91-105, 1992.

Nott, J.: Long-term drainage evolution in the Shoalhaven catchment, southeast highlands, Australia, Earth Surface Processes and Landforms, 17, 361-374, 1992.

Oguchi, T.: Geomorphological and environmental settings of Tell Kosak Shamali, Syria, in: Tell Kosak Shamali, the Archaeological Investigations on the Upper Euphrates, Syria: vol. 1, edited by: Nishiaki, N. and Matsutani, T., Oxbow, Oxford, England, p. 19-40, 2001.

Ponikarov, V.: Geological map of the Jarablus (J-37-III) quadrangle, 1:200 000 scale, Technoexport, Moscow, and Ministry of Industry, Syrian Arab Republic, Damascus, 1966.

Ponikarov, V. P., Kazmin, V. G., Mikhailov, I. A., Razvaliayev, A. V., Krasheninnikov, V. A., Kozlov, V. V., Soulidi-Kondratiyev, E. D., Mikhailov, K. Y., Kulakov, V. V., Faradzhev, V. A., and Mirzayev, K. M.: The Geology of Syria: Explanatory notes on the geological map of Syria, scale 1:500,000. Part I: Stratigraphy, Igneous Rocks, and Tectonics, Technoexport, Moscow, and Ministry of Industry, Syrian Arab Republic, Damascus, 1967.

Renne, P. R., Swisher, C. C., Deino, A. L., Karner, D. B., Owens, T. L., and DePaolo, D. J.: Intercalibration of standards, absolute ages and uncertainties in ${ }^{40} \mathrm{Ar} /{ }^{39} \mathrm{Ar}$ dating, Chemical Geology 145, 117-152, 1998

Rigo de Righi, M. and Cortesini, A.: Gravity tectonics in Foothills Structure Belt of southeast Turkey, American Association of Petroleum Geologists' Bulletin, 48, 1911-1937, 1964.
Sanlaville, P.: Les terraces Pléistocènes de la vallée de l'Euphrate en Syrie et dans l'extrême sud de la Turquie, British Archaeological Reports, Int. Ser., 1263, 115-133, 2004.

Seyrek, A., Demir, T., Pringle, M., Yurtmen, S., Westaway, R., Beck, A., and Rowbotham, G.: Kinematics of the Amanos Fault, southern Turkey, from Ar-Ar dating of offset Pleistocene basalt flows: transpression between the African and Arabian plates, in: Tectonics of Strike-Slip Restraining and Releasing Bends, edited by: Cunningham, D. and Mann, P., Geological Society, London, Special Publication, in press, 2007.

Steiger, R. H., and Jäger, E.: Convention on the use of decay constants in geo- and cosmochronology, Earth Planet. Sci. Lett., 36, 359-363, 1977.

Stevenson, A. and Brown, C.: The ancient Murray River system, Bureau of Mineral Resources Journal of Australian Geology and Geophysics, 11, 387-395, 1989.

Terlemez, H.Ç. İ., Şentürk, K., Sümengen, M., and Oral, A.: Geological map of the Antakya - L24 quadrangle, 1:100 000 scale, and accompanying 11 page explanatory booklet, General Directorate of Mineral Research and Exploration, Ankara, 1997.

Tyráček, J.: Terraces of the Euphrates River, Sborník geologických Věd, Antropozoikum, 18, 185-202, 1987.

Ulu, Ü.: Geological map of the Suruç - L25 quadrangle, 1:100 000 scale, and accompanying 9 page explanatory booklet, General Directorate of Mineral Research and Exploration, Ankara, 1996.

Westaway, R.: Kinematic consistency between the Dead Sea Fault Zone and the Neogene and Quaternary left-lateral faulting in SE Turkey, Tectonophysics, 391, 203-237, 2004.

Westaway, R., Bridgland, D., Challis, K., and White, M.: A dating framework for the Lower and Middle Palaeolithic in Levantine rivers, Council for British Research in the Levant Newsletter, 3133, 2005a.

Westaway, R., Guillou, H., Yurtmen, S., Demir, T., and Rowbotham, G.: Constraints on the timing and regional conditions at the start of the present phase of crustal extension in western Turkey from observations in and around the Denizli region, Geodinamica Acta, 18, 209-238, 2005b.

Westaway, R., Demir, T., Seyrek, A. and Beck, A.: Kinematics of active left-lateral faulting in southeast Turkey from offset Pleistocene river gorges: improved constraint on the rate and history of relative motion between the Turkish and Arabian plates, J. Geol. Soc., London, 163, 149-164, 2006a.

Westaway, R., Guillou, H., Yurtmen, S., Beck, A., Bridgland, D., Demir, T., Scaillet, S., and Rowbotham, G.: Late Cenozoic uplift of western Turkey: Improved dating of the Kula Quaternary volcanic field and numerical modelling of the Gediz river terrace staircase, Global and Planetary Change, 51, 131-171, $2006 \mathrm{~b}$.

Westaway, R., Pringle, M., Yurtmen, S., Demir, T., Bridgland, D., Rowbotham, G., and Maddy, D.: Pliocene and Quaternary regional uplift in western Turkey: The Gediz river terrace flight and the volcanism at Kula, Tectonophysics, 391, 121-169, 2004.

Yurtmen, S., Guillou, H., Westaway, R., Rowbotham, G., and Tatar, O.: Rate of strike-slip motion on the Amanos Fault (Karasu Valley, southern Turkey) constrained by K-Ar dating and geochemical analysis of Quaternary basalts, Tectonophysics, 344, 207246, 2002. 